\title{
Disinfection of dental impressions in dental colleges in India: a cause of concern
}

\author{
Charu Mohan Marya, Prasoon Shukla, Vandana Dahiya, Niraj Rampal \\ Sudha Rustagi College of Dental Sciences \& Research, Faridabad, Haryana, India
}

doi: 10.3396/ijic.V6i1.008.10

Microbial flora of oral cavity is rich \& extremely diverse. This reflects abundant nutrients, moisture, hospitable temperature \& availability of surfaces on which microbial populations can develop \& a number of them cause infections that may be uncurable. ${ }^{1}$

Previous reports confirmed that all members of the dental profession are at a risk at least three times greater than the general population of contacting infection and developing the carrier state. ${ }^{2}$ Hepatitis B poses a high risk to dental staff with it's relatively low infective dose and stability outside body for lengthy periods. ${ }^{3,4,5}$ It is estimated that, India with a population of nearly one billion, harbors no less than 30 million chronic carriers of the hepatitis B virus (HBV). ${ }^{2}$ Also, India is now among the leading countries for numbers of cases of AIDS; if the situation remains unchanged, the number of such cases could reach 50 million by 2025. ${ }^{2}$ Tuberculosis remains another leading cause of death in India, claiming nearly 400,000 fatalities annually. ${ }^{2}$
Casts from contaminated dental impressions are known to carry a variety of pathogens and disinfection guidelines, such as those from the U.S. Centers for Disease Control \& Prevention, caution that all patients be considered potentially infectious. . $^{2,6,7,8,9,10}$ Therefore, proper disinfection of contaminated dental impressions \& other dental items leaving the immediate chair-side area remains the best approach to preventing the spread of infections in dentistry. ${ }^{1}$ Among the currently recommended, disinfectants for this purpose are formaldehyde, glutaraldehyde, chlorine compounds, iodophores \& phenolics in adequate concentrations. ${ }^{11,12,13}$

Sixty randomly selected dental colleges across India were surveyed by e-mail to assess the current status of routine practices for treating the impressions prior to pouring of casts. The purpose of the study along with a short questionnaire was sent to a suitable academic at each college. The third and final wave of mailings generated a total of 57 responses; 3 of these were incomplete and were not included in the analysis.

\section{Corresponding author}

Dr. Charu Mohan Marya, Professor and Head Department of Community Dentistry, Sudha Rustagi College of Dental Sciences \&Research, Faridabad, Haryana, India, 121002.

Tel: +91-9811144408, Fax: +91-129-2202951, Email: maryacm@yahoo.co.uk 
Out of 54, chemical disinfectants were available in 36 departments (66.7\%). Forty-one participants (75.9\%) reported that they simply washed the impressions under running water between patients, while 13 participants $(24 \%)$ reported that the impressions were disinfected.

As confirmed by this survey, most dental colleges still routinely wash the impressions in running water even though the available literature clearly shows such a practice to be inadequate from a microbiological perspective. ${ }^{14,15}$ Therefore, dental colleges in India should immediately review the situation and introduce corrective measures, including additional training of dental technicians \& other dental auxiliary personnel as well as establish effective and routine disinfection practices.

\section{References}

1. Twomey JO, Abdelaziz KM, Combe EC, Anderson DL. Calcium hypochlorite as a disinfecting additive for dental stone. I Prosthet Dent 2003; 90: 282-288.

2. Kohli A, Puttiah R. Infection control and occupational safety recommendations for oral health professionals. $1^{\text {st }}$ ed. New Delhi: Dental council of India, 2007 p13.

3. Runnels RR. An overview of infection control in dental practice. J Prosthet Dent 1988; 59: 625-629.

4. Davids GR, Porra M. The need for post-vaccination serology \& timing of booster vaccinations against hepatitis B in dental health care workers. Aust Dent / 1994; 39: 238-241.
5. Runnels RR. Infection control in wet finger environment. $1^{\text {st }}$ ed. Salt Lake City, Utah: IC publications, 1984 p36.

6. Centers for Disease Control. Guidelines for infection control in dental health care settings - 2003. MMWR 2003; 52 (RR-17): 1-66. Available at www.cdc.gov/ oralhealth/ infectioncontrol.

7. Firtell DN, More DJ, Pelleu GB Jr. Sterilization of impression materials for use in surgical operating room. J Prosthet Dent 1972; 27: 419-422.

8. Rowe AH, Forrest JO. Dental impressions. The probability of contamination \& method of disinfection. Br Dent / 1978; 145: 184-186.

9. Leung RL, Schonfeldt SE. Gypsum casts as potential source of microbial cross contamination. J Prosthet Dent 1983; 49: 210211.

10. Merchant VA. Infection control \& Prosthodontics. J Calif Dent Assoc 1989; 17: 48-53.

11. Lepe $\mathrm{X}$, Johnson GH, Berg JC. Surface characterstics of polyether \& addition silicon impression materials after long term disinfection. I Prosth Dent 1995; 74: 181-186.

12 Hilton TJ, Schwartz RS, Bradley DV. Impression disinfection of irreversible hydrocolloid impressions. Part 2: effects on gypsum casts. Int J Prosthodont 1994; 7: 424-433.

13. Matyas J, Dao N, Capputo AA, Lucatorto FM. Effect of disinfectants on dimensional accuracy of impression materials. J Prosth Dent 1990; 64: 25-31.

14. Abdelaziz KM, Combe EC, Hodges JS. The effect of disinfectants on the properties of dental gypsum: 1. Mechanical properties. J Prosthodont 2002; 11: 161-167.

15. Sofou A, Larsen T, Owall B, Fiehn NE. In vitro study of transmission of bacteria from contaminated metal models to stone models via impressions. Clin Oral Investig 2002; 6: 166170. 